\title{
TITONIA DAN JERAMI PADI YANG DIKOMPOSKAN TERHADAP CIRI KIMIA TANAH DAN PRODUKSI JAGUNG PADA ULTISOL
}

\author{
Gusnidar*, Annisa Fitri, dan Syafrimen Yasin \\ Prodi Ilmu Tanah Fakultas Pertanian Universitas Andalas Padang Sumatera Barat 25163 \\ *Email: gusnidar.a02@gmail.com; hp+6281363389265
}

\begin{abstract}
Abstrak
Ultisol merupakan tanah suboptimal yang perlu dikembangkan untuk meningkatkan ketersediaan pangan dan pakan karena cukup luas, namun mempunyai kendala fisika dan kimia tanah. Penelitian bertujuan untuk mempelajari pemberian kompos asal titonia (Tt) dan jerami padi (JP) untuk memperbaiki ciri kimia Ultisol serta pengaruhnya terhadap produksi jagung. Percobaan berlangsung di Laboratorium Tanah dan rumah kaca Fakultas Pertanian Universitas Andalas Padang, Sumatera Barat, mulai Januari sampai Juli 2017. Penempatan perlakuan menurut pola Rancangan Acak

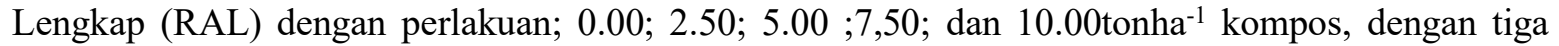
ulangan. Data analisis tanah diuji dengan kriteria penilaian ciri kimia tanah, dan data tanaman diuji F, data yang berbeda nyata dilanjutkan dengan uji DNMRT taraf 0.05. Hasil penelitian menunjukkan bahwa dosis optimum untuk memperbaiki ciri kimia Ultisol serta pengaruhnya terhadap produksi jagung adalah 7.50 tonha $^{-1}$. Pada dosis tersebut, nilai $\mathrm{pH}$ tanah mencapai 6,18 satuan; P-ters sebesar 17,64ppm, Kapasitas Tukar Kation (KTK) $18,38 \mathrm{cmol}(\mathrm{kg})^{-1}, \mathrm{C}_{\text {-org }}, 1.27 \%$, $\mathrm{N}_{\text {tot. }}$. $0,23 \%, \mathrm{~K}$-dd $0,49 \mathrm{cmol}\left(\mathrm{kg}^{-1} ; \mathrm{Ca}_{-d d} 2.63 \mathrm{cmol}(\mathrm{kg})^{-1} ; \mathrm{Mg}_{- \text {dd }} 0,57 \mathrm{cmol}(\mathrm{kg})^{-1}\right.$ dan Na-dd $0,39 \mathrm{cmol}(\mathrm{kg})^{-1}$; dengan produksi jagung optimum sebanyak 85,48gpot ${ }^{-1}$; bobot jerami sebesar 75,84 gpot $^{-1}$ dan bobot 100 biji sebanyak $25,50 \mathrm{~g}$.
\end{abstract}

Kata kunci: jagung, kompos tittonia campur jerami, Ultisol

\section{TITONIA AND RICE STRAW COMPOSTING TO PROPERTIES ULTISOL AND CORN PRODUCTION}

\begin{abstract}
Ultisol is broad suboptimal soils, need to be developed to increase for foods and animal feeds, but properties of physics and chemistry by the soils bad. This research was aimed to studied the influence of compost derived from titonia plus rice straw in improving chemical properties of Ultisol and corn production. This researh was conducted in glasshouse and Soil Laboratory of Agriculture Faculty, Andalas University, Padang, West Sumatra, Indonesia from January to July 2017. The experiment consisted of 5 treatments $\left(0.00 ; 2.50 ; 5.00 ; 7.50 ; 10.00\right.$ tonha $^{-1}$. with 3 replications. Soil data resulted were compared to the soil criteria, while corn data were statistically analyzed the variance and continued using DNMRT at 0.05 level of significance, if F-calculated $>$ F-table. The results of research showed that optimum dosage for repaired chemical properties of 7,50 tonha $^{-1}$. It dosage soil $\mathrm{pH} 6,18$ unit; available $\mathrm{P}$ by $17,64 \mathrm{ppm}$; CEC by $18,38 \mathrm{cmol}(\mathrm{kg})^{-1}$; organic-C by $1,27 \%$, total-N by $0,23 \%$; K-exch. by $0,49 \mathrm{cmol}(\mathrm{kg})^{-1}$; Ca-exch. by $2,63 \quad \mathrm{cmol}(\mathrm{kg})^{-1}$; Mg-exch. by $0,57 \mathrm{cmol}(\mathrm{kg})^{-1}$ dan Na-exch. by $0,39 \mathrm{cmol}(\mathrm{kg})^{-1}$, with dry weight of seed by $85,48 \mathrm{gpot}^{-}$ ${ }^{1}$; dry weight of straw by 75,84 gpot $^{-1}$ and dry weight of 100 seed by $25,50 \mathrm{~g}$.
\end{abstract}

Key words : Compost derived from titonia plus rice straw, corn, Ultisol.

(C) 2019 Gusnidar Gusnidar, Annisa Fitri, Syafrimen Yasin 


\section{PENDAHULUAN}

Lahan kering di Indonesia lebih dari separuh daratan (78\% luas daratan), salah satunya adalah lahan dengan ordo Ultisol. Ultisol merupakan lahan kering suboptimal yang terluas di Indonesia (45.794.000 ha) atau sekitar $25 \%$ total daratan Indonesia. Tersebar di Kalimantan (21.938.000 ha), Sumatera (9.469.000 ha), Maluku dan Papua (8.859.000 ha), Sulawesi (4.303.000 ha), Jawa (1.172.000 ha), dan Nusa Tenggara (53.000 ha) (Subagyo et al., 2004). Landscapenya datar, bergelombang, berbukit sampai bergunung. Tanah ini berkembang dari berbagai bahan induk masam, dengan kejenuhan basa (KB) $<35 \%$ dan ditemui horizon Argilik.

Tanah ini memiliki akumulasi liat pada horizon bawah permukaan. Mineral yang dominan adalah liat tipe 1:1 (Kaolinit). Permeabilitas tanah rendah sehingga kurang meloloskan air dan mudah tererosi. Penampang tanahnya dalam, dan kadar liat semakin tinggi pada lapisan bawah. Jika diusahakan untuk lahan budidaya tanaman pangan, seperti jagung, mempunyai beberapa kendala. Teknologi pengapuran sudah diyakini dapat mengatasi masalah rendahnya $\mathrm{pH}$ dan tingginya kelarutan $\mathrm{Al}_{-\mathrm{dd}}$ (Aluminium yang dapat dipertukarkan), serta dapat meningkatkan ketersediaan hara berupa $\mathrm{N}$ (nitrogen), $\mathrm{P}$ (posfor), $\mathrm{K}$ (kalium), $\mathrm{Ca}$ (kalsium), Mg (magnesium) dan unsur lainnya. Penggunaan kapur sebagai amelioran akan lebih baik, jika ditambah dengan bahan organik (BO).

Bahan organik banyak macamya, antara lain tumbuhan paitan (Titonia) dan limbah panen padi berupa jerami. Campuran kedua bahan ini (1:1) yang dikomposkan diyakini mampu memperbaiki ketersediaan hara beberapa jenis tanah sub optimal, seperti Oxisol, Inceptisol, Regosol (Gusnidar et al, 2011; Yasin et al, 2015; Gusnidar, et al, 2017). Titonia dan JP (1:1) yang dikomposkan ketersediaan haranya lebih baik dibandingkan dengan jerami saja.

Secara fisik $\mathrm{Tt}$ tak perlu dikomposkan, namun, jika waktu pangkasnya di luar jadwal pengolahan lahan, akan lebih baik dimanfaatkan untuk kompos daripada terbuang atau terlalu tua. Selain itu, hasil pangkasannya, dapat memperbaiki mutu kompos, bila hanya bahan kompos dari jerami saja. Disisi lain JP belum maksimal pemanfaatannya, sering dibakar atau dibawa keluar lahan untuk pakan ternak.

Tanaman indikator dipilih jagung karena sumber pangan dan pakan yang perlu ditingkatkan produksinya. Jagung adalah bahan pakan utama dalam budidaya ternak. Indonesia masih mengimpor jagung sebesar 1,46 juta ton, karena produksi baru mencapai 18,3 juta ton (2009-2013) (Deptan, 2015). Untuk meningkatkan produksi pemerintah telah melaksanakan program Upsus Pajale (Upaya Khusus Peningkatan Produksi Padi Jagung dan Kedelai), dan dilanjutkan pada tahun 2016-2017. Pada program tersebut dilakukan perluasan areal tanam (PAT) dan peningkatan teknologi usaha tani. Untuk PAT, lahan yang tersedia ada yang bermasalah dan banyak kendala fisik dan kimia, sehingga diperlukan input untuk perbaikan yang mudah dan murah. Tujuannya adalah untuk mempelajari pengaruh $\mathrm{Tt}$ dan JP yang dikomposkan terhadap ciri kimia Ultisol dan produksi tanaman jagung.

\section{BAHAN DAN METODA}

Percobaan di rumah kaca dan laboratorium Tanah Fakultas Pertanian Universitas Andalas, sejak Januari - Juli 2017. Tanah diambil dari farm Fakultas Pertanian Unand di Limau Manis Padang. Kompos asal Tt danJP (1:1), benih jagung, pupuk berupa Urea, SP-36, KCl, dan lain-lain.

Bentuk percobaan rancangan acak lengkap (RAL), 5 perlakuan $(0.00 ; 2.50 ; 5.00$; 7.50 dan 10.00 ton komposha $^{-1}$ ) dengan 3 ulangan. Kompos matang, dikering anginkan diukur kadar airnya (KA), selanjutnya ditetapkan kebutuhan kompos. Pot diisi dengan tanah setara $10 \mathrm{~kg}$ berat kering mutlak (BKM), diberi kapur Dolomit setara 1.5 x Al-dd (setara 6.80 ton ha $^{-1}$ ) Tanah, kapur dan kompos diaduk rata, diberi air sampai kapasitas lapang (KL), diinkubasi selama 14 hari. Akhir waktu inkubasi, media diaduk rata, diambil sampel tanah sebanyak $50 \mathrm{~g}$, untuk dianalisis ciri kimia 
tanahnya. Benih jagung 2 biji pot $^{-1}$ yang telah direndam ditanamkan sedalam $3 \mathrm{~cm}$ dari permukaan tanah.

Tanaman yang telah berumur 7 hari setelah tanam (HST), diseleksi 1 tanamanpot ${ }^{-1}$. Selanjutnya dipupuk dengan Urea setara 300 $\mathrm{kg} \mathrm{ha}^{-1}$, SP-36 setara $100 \mathrm{~kg} \mathrm{ha}^{-1}$, dan $\mathrm{KCl}$ setara $100 \mathrm{~kg} \mathrm{ha}^{-1}$. Pupuk SP-36 dan $\mathrm{KCl}$ dibenamkan sekitar tanaman, Urea diberikan saat tanam dan umur 21 HST, masing-masing setengah dosis.

Pengamatan tanah awal dan sesudah diinkubasi (SI) dengan kapur dan kompos meliputi; $\mathrm{pH}\left(\mathrm{H}_{2} \mathrm{O}\right.$ 1:1), $\mathrm{N}_{\text {-tot }}$ (Kjeldahl), $\mathrm{P}_{\text {-ters. }}$ (Bray-1), C-Org. (Walkley dan Black), $\mathrm{Al}_{-\mathrm{dd}}$ (Volumentri), KTK dan basa-basa (K, Na, Ca, dan $\mathrm{Mg}_{\text {-dd }}$ ) dengan pencucian Amonium asetat $1 \mathrm{~N}, \mathrm{pH} 7$, dan ditetapkan kriteria haranya. Pengamatan tanaman, berupa tinggi tanaman, bobot kering jerami pot $^{-1}$, bobot kering bijipot $^{-1}$, bobot 100 biji serta kadar hara $\mathrm{N}, \mathrm{P}$, dan $\mathrm{K}$. Data yang diperoleh diuji $\mathrm{F}$, jika signifikan dilakukan uji DNMRT pada taraf 0.05.

\section{HASIL DAN PEMBAHASAN \\ Kompos dan tanah yang digunakan dalam penelitian}

Kompos yang digunakan dalam percobaan mempunyai komposisi kimia seperti pada Tabel 1, dan ciri kimia tanah awal dan SI dengan kapur dan kompos pada Tabel 2.

Tabel 1. Komposisi kompos Tt+JP (1:1) yang digunakan untuk penelitian

\begin{tabular}{ccr}
\hline Komposisi kimia kompos & Satuan & Nilai \\
\hline C-total & $\%$ & 27.11 \\
N-total & $\%$ & 1.55 \\
C/N & - & 17.49 \\
P-total & $\%$ & 0,33 \\
K-total & $\%$ & 0.88 \\
Ca-total & $\%$ & 0.03 \\
Mg-total & $\%$ & 0.02 \\
\hline
\end{tabular}

Kompos yang digunakan kualitasnya cukup bagus dan telah memenuhi Standar Nasional Indonesia (SNI). Semua komponen hara yang dikandung kompos $\mathrm{Tt}+\mathrm{JP}$ telah melewati nilai batas minimun yang disyaratkan, dan nilai $\mathrm{C} / \mathrm{N}$ nya rendah (17.49) atau di bawah 20. Hal tersebut mengindikasikan bahwa kompos telah dapat diaplikasikan ke tanah serta bahan asal kompos telah termineralisasi, Diharapkan aplikasi kompos ini ke tanah dapat memperbaiki pertumbuhan tanaman jagung pada Ultisol.

Stevenson (1994) menyatakan bahwa BO yang telah lapuk, ditandai dengan $\mathrm{C} / \mathrm{N}$ rendah, mengandung $\mathrm{N}$ dalam bentuk $\mathrm{NH}_{3}$. Senyawa ini selanjutnya dapat menjadi nitrit dan nitrat sehingga dapat diserap tanaman. Bahan organik dengan $\mathrm{C} / \mathrm{N}<20$ berarti telah terjadinya mineralisasi. Jika $\mathrm{C} / \mathrm{N}>30$ maka immobilisasi $\mathrm{N}$ yang terjadi. Untuk $\mathrm{C} / \mathrm{N}$ antara $20-30$ berarti terjadi keseimbangan proses mineralisasi dengan immobilisasi. Pada saat itu, bisa terjadi kompetisi hara (nutrisi) antara tanaman dan mikroorganisme. Oleh sebab itu diperlukan penambahan suplai hara.dengan pupuk kimia buatan.

Ultisol sebagai media tanam kurang subur (Tabel 2), reaksi tanah masam dan ketersediaan hara sangat rendah sampai rendah. Kation basa juga sangat rendah sampai rendah, sehingga kapasitas tukar kation (KTK) menjadi rendah. Di lain pihak Al-dd $>2 \mathrm{cmol}_{(\mathrm{kg})^{-1}}$. Diharapkan pemberian kompos yang disertai pengapuran dapat memperbaiki kesuburan tanah, agar pertumbuhan tanaman jagung optimal.

Kejenuhan Al yang tinggi dan ketersediaan unsur hara yang rendah seperti hara $\mathrm{K}, \mathrm{Ca}$, dan $\mathrm{Mg}$ serta $\mathrm{P}$, pada Ultisol telah banyak ditulis dalam literatur. Soepardi (1983), dan Tan (2010) menyatakan bahwa kadar Al yang tinggi pada Ultisol berasal dari hasil 
pelapukan mineral yang mudah lapuk karena merupakan tanah tua dan berumur lanjut. Reaksinya pengikatan $\mathrm{P}$ oleh $\mathrm{Al}$ seperti tertera di bawah ini.

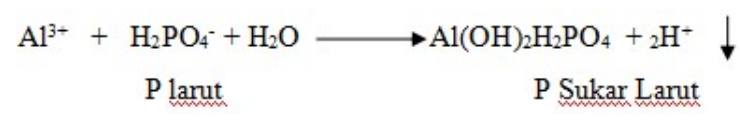

Tabel 2. Sifat kimia Ultisol awal dan SI dengan kapur dan kompos TT $+\mathrm{JP}$

\begin{tabular}{|c|c|c|c|c|c|c|c|c|c|c|c|c|c|}
\hline \multirow{2}{*}{$\begin{array}{c}\text { Jenis } \\
\text { analisis }\end{array}$} & \multirow[t]{2}{*}{ Satuan } & \multirow{2}{*}{\multicolumn{2}{|c|}{$\begin{array}{c}\text { Tanah } \\
\text { awal }\end{array}$}} & \multicolumn{10}{|c|}{ Perlakuan kompos $(\mathrm{Tt}+\mathrm{JP})$ dalam tonha ${ }^{-1}$} \\
\hline & & & & 0.00 & & 2.50 & & 5.00 & & 7.50 & & 10.00 & \\
\hline $\mathrm{pH}\left(\mathrm{H}_{2} \mathrm{O}\right)$ & & 5.1 & & $6.13 \mathrm{a}$ & & 6.14 & & 6.18 & & 6.18 & & $6.20 \mathrm{a}$ & \\
\hline $\mathrm{C}$-org & $\%$ & 0.87 & $\mathrm{sr}$ & 1.08 & $\mathrm{r}$ & 1.24 & $\mathrm{r}$ & 1.25 & $\mathrm{r}$ & 1.27 & $\mathrm{r}$ & 1.27 & 1 \\
\hline $\mathrm{N}-$ tot & $\%$ & 0.14 & $\mathrm{r}$ & 0.18 & $\mathrm{r}$ & 0.22 & $\mathrm{~s}$ & 0.22 & $\mathrm{~s}$ & 0.23 & $\mathrm{~s}$ & 0.24 & $\mathrm{~s}$ \\
\hline$P_{\text {-ters }}$ & ppm & 13.56 & $\mathrm{r}$ & 14.32 & $\mathrm{r}$ & 15.29 & $\mathrm{r}$ & 16.85 & $\mathrm{r}$ & 17.64 & $\mathrm{~s}$ & 17.99 & $\mathrm{~s}$ \\
\hline $\mathrm{Al}-\mathrm{dd}$ & $\operatorname{cmol}(\mathrm{kg})^{-1}$ & 2.47 & & tu & & tu & & tu & & tu & & tu & \\
\hline $\mathrm{K}-\mathrm{dd}$ & $\operatorname{cmol}(\mathrm{kg})^{-1}$ & 0.37 & $\mathrm{r}$ & 0.37 & $\mathrm{r}$ & 0.46 & $\mathrm{~s}$ & 0.47 . & $\mathrm{s}$ & 0.49 & $\mathrm{~s}$ & 0.52 & $\mathrm{~S}$ \\
\hline $\mathrm{Na}-\mathrm{dd}$ & $\operatorname{cmol}(\mathrm{kg})^{-1}$ & 0.30 & $\mathrm{r}$ & 0.31 & $\mathrm{r}$ & 0.36 & $\mathrm{r}$ & 0.37 & $\mathrm{r}$ & 0.39 & $\mathrm{r}$ & 0.41 & $\mathrm{~s}$ \\
\hline $\mathrm{Ca}-\mathrm{dd}$ & $\operatorname{cmol}(\mathrm{kg})^{-1}$ & 2.24 & $\mathrm{r}$ & 2.49 & $\mathrm{r}$ & 2.50 & $\mathrm{r}$ & 2.59 & $\mathrm{r}$ & 2.63 & $\mathrm{r}$ & 2.81 & $\mathrm{r}$ \\
\hline Mg-dd & $\mathrm{cmol}(\mathrm{kg})^{-1}$ & 0.37 & $\mathrm{sr}$ & 0.50 & $\mathrm{r}$ & 0.50 & $\mathrm{r}$ & 0.51 & $\mathrm{r}$ & 0.57 & $\mathrm{r}$ & 0.60 & $\mathrm{r}$ \\
\hline KTK & $\operatorname{cmol}(\mathrm{kg})^{-1}$ & 11.92 & $\mathrm{r}$ & 13.21 & $\mathrm{r}$ & 14.59 & $\mathrm{r}$ & 16.69 & $\mathrm{r}$ & 18.38 & $\mathrm{~s}$ & 19.65 & $\mathrm{~s}$ \\
\hline Kej.Al & $\%$ & 57.04 & & tu & & tu & & tu & & tu & & tu & \\
\hline KB & $\%$ & 27.52 & & 29.97 & & 26.18 & & 23.61 & & 22.25 & & 22.09 & \\
\hline
\end{tabular}

Keterangan: m-masam; am=agak masam; sr=sangat rendah; r=rendah; s=sedang; tu=tidak terukur.

Unsur Al adalah penyebab kemasaman tanah. Setiap satu Al dengan muatan 3 positif akan menyumbangkan 3 ion $\mathrm{H}^{+}$. Kemasaman dan kejenuhan $\mathrm{Al}$ yang tinggi ini dapat dinetralisir dengan pengapuran (Hakim, 1982; Soepardi, 1983). Selain kapur, BO berupa kompos juga dapat memperbaiki ciri kimia, fisika dan biologi Ultisol.

Jika diperhatikan ciri kimia tanah SI dengan kapur dan beberapa dosis kompos, terlihat bahwa terjadi sedikit perbaikan, namun ketersediaan hara belum seimbang. Kenaikan kriteria ketersediaan hara terbaik dicapai pada input kompos 10.00 ton $\mathrm{ha}^{-1}$, yang tidak terlalu berbeda dengan dosis 7.50 ton $\mathrm{ha}^{-1}$ Nilai $\mathrm{pH}$ masih agak masam, $\mathrm{C}_{\text {-org., }} \mathrm{N}_{\text {-tot. }}$ dan $\mathrm{P}_{\text {-ters. }}$ hanya mampu mencapai kriteria sedang (s). Begitu juga untuk K-dd, Na-dd dan KTK dalam kriteria yang sama (s). Untuk kadar $\mathrm{Ca}-\mathrm{dd}$ dan $\mathrm{Mg}_{\text {-dd }}$ masih rendah (r).

Reaksi tanah yang agak masam, serta kadar P-tersedia tanah yang masih rendah, menunjukkan bahwa input kompos yang diberikan, setelah 2 minggu inkubasi belum banyak merobah ciri kimia tanah. Kadar Al yang tinggi pada Ultisol, akan mengikat $\mathrm{P}$, sehingga terbentuk senyawa Aluminium fosfat yang sukar larut. Keadaan tersebut menyebabkan hara $\mathrm{P}$ tidak tersedia bagi tanaman. Namun dengan diiring dengan pemberian kapur, $\mathrm{Al}_{-\mathrm{dd}}$ sudah dapat dikendalikan.

Fospor merupakan salah satu unsur hara makro essensial yang sangat menentukan pertumbuhan dan perkembangan tanaman. Jika tanaman kekurangan $\mathrm{P}$, maka pertumbuhan tanaman tidak normal. Kemampuan BO mengikat mineral oksida bermuatan positif terutama kation $\mathrm{Al}$ dan $\mathrm{Fe}$ yang reaktif menyebabkan fiksasi $\mathrm{P}$ berkurang.. Asam-asam organik hasil dekomposisi $\mathrm{BO}$ melarutkan $\mathrm{P}$ dan unsur lain yang terikat oleh $\mathrm{Al}$, sehingga $\mathrm{P}$ dapat tersedia bagi tanaman (Sorpardi, 1983; Hanafiah, 2007). Peristiwa tersebut dapat digambarkan seperti reaksi berikut:
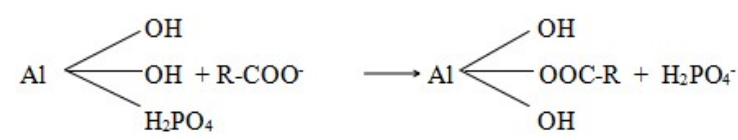
Nilai $\mathrm{C}$-org tanah awal juga sangat rendah $(0,87 \%)$. Seiring dengan itu kadar $\mathrm{N}_{\text {-tot }}$ tanah awal juga rendah $(0,14 \%)$. Nilai KTK sebesar $11,92 \mathrm{cmol}(\mathrm{kg})^{-1}$ (rendah). Ultisol tergolong tanah mineral masam dengan pelapukan lanjut, dan telah terjadi pencucian kation basa $(\mathrm{K}, \mathrm{Na}$, $\mathrm{Ca}$, dan $\mathrm{Mg}$ ), akibatnya nilai Kejenuhan basa (KB) juga rendah. Kation yang dapat ditukarkan juga dalam kriteria sangat rendah sampai rendah. Hanafiah (2007), menjelaskan bahwa drainase yang baik sangat mendukung terbentuknya mineral kaolinit. Tan (2010) menjelaskan bahwa nilai KTK mineral Kaolinit

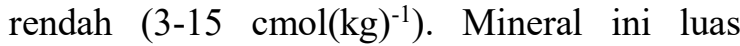
permukaan jerapan koloid tanahnya kecil (7-30 $\mathrm{m}^{2}(\mathrm{~g})^{-1}$. Luas permukaan koloid mempengaruhi besarnya ion yang terjerap dan dapat dipertukarkan. Semakin luas permukaan koloid maka semakin banyak ion yang dapat dijerap dan dipertukarkan

Titonia segar ataupun $\mathrm{Tt}$ yang dibenamkan ke dalam tanah mampu menghasilkan AO seperti asam malat, asam sitrat, asam salisilat, asam tartarat (Gusnidar e.t al., 2010). Senesi et al (2009) menyatakan bahwa BO dapat meningkatkan jumlah dan aktivitas jasad renik dalam tanah serta membantu dekomposisi BO tersebut. Menurut Sudaryono (2009), BO secara kimia tersusun dari 44\% Karbon $(\mathrm{C}), 8 \%$ Hidrogen $(\mathrm{H}), 40 \%$ Oksigen $(\mathrm{O})$, dan $8 \%$ bahan mineral .

Komposisi kompos seperti pada Tabel 2, telah memperbaiki ciri kimia Ultisol (Tabel 3). Namun kenaikan kadar hara belum optimal, karena belum merubah nilai kriteria ke level yang cukup untuk pertumbuhan tanaman.. Rata-rata kriteria parameter yang diamati berkisar di kriteria rendah sampai sedang, kecuali untuk $\mathrm{Al}_{\text {-dd }}$ dan kejenuhan $\mathrm{Al}$ sudah tidak terukur (tu). Hal ini dapat diartikan bahwa pengaruh jelek Al sudah dapat dditiadakan akibat input kapur yang diberikan bersama kompos.

\section{Pengamatan terhadap tanaman}

Tinggi tanaman dalam periode tertentu adalah cerminan pertumbuhan tanaman secara vegetatif (Gambar 1). Penggunan berbagai dosis kompos tidak terlalu berbeda pengaruhnya terhadap pertambahan tinggi tanaman sampai $54 \mathrm{HST}$, namun ceenderung lebih baik pada dosis 7.50 sampai 10.00 ton $\mathrm{ha}^{-1}$. Untuk kecukupan hara $\mathrm{N}$, input kompos 2.50 sampai 10.00 ton $\mathrm{ha}^{-1}$, relatif sama. Sedangkan untuk kecukupan hara $\mathrm{P}$, input kompos 5.00 sampai 10.00 ton $\mathrm{ha}^{-1}$ juga tidak berbeda nyata, dan relatif sama untuk kecekupan hara K (Tabel 3).

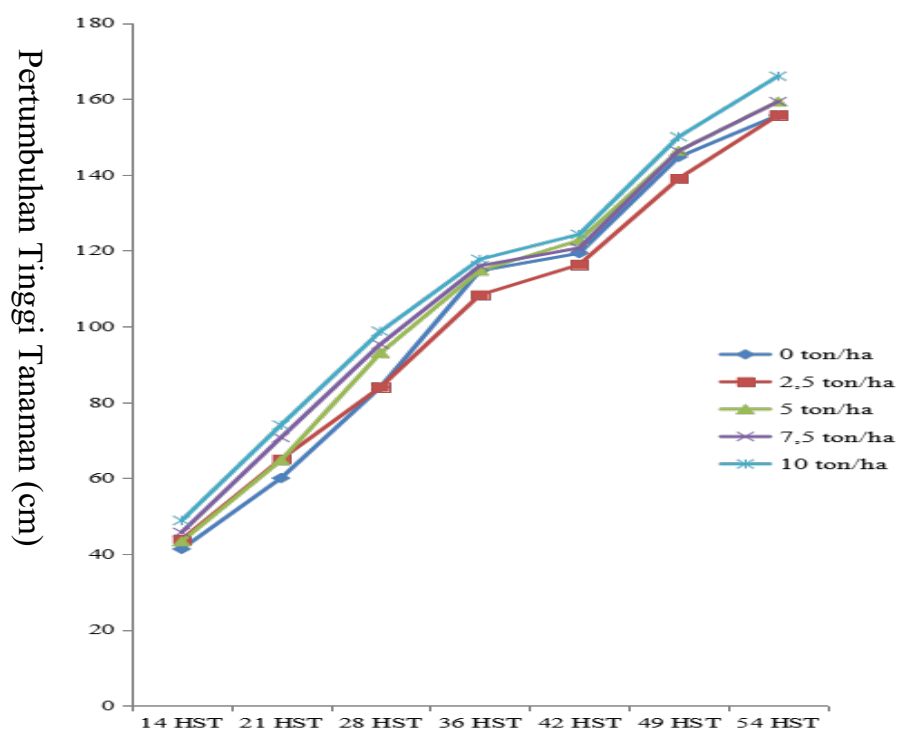

Gambar 1. Pertambahan tinggi tanaman jagung akibat pemberian kompos $\mathrm{Tt}+\mathrm{JP}$ 
Pengamatan generatif tanaman kering biji, dan bobot kering 100 biji (Tabel 3). dilakukan terhadap bobot kering jerami, bobot

Tabel 3. Hasil pengamtan terhadap tanaman jagung yang diberi kompos $\mathrm{Tt}+\mathrm{J}$ jerami $(1: 1)$

\begin{tabular}{|c|c|c|c|c|c|c|c|}
\hline \multirow{2}{*}{$\begin{array}{l}\text { Kompos } \\
\mathrm{Tt}+\mathrm{JP} \\
\left(\text { tonha }^{-1}\right)\end{array}$} & \multicolumn{3}{|c|}{ Kecukupan hara (\%) } & \multicolumn{4}{|c|}{ Bobot kering (g) } \\
\hline & N-total & P-total & K-total & jerami & biji & & 100 biji \\
\hline 0.00 & $2,14 \mathrm{~b}$ & $0,16 \mathrm{~b}$ & 1,34 & $59,60 \mathrm{~b}$ & 18,29 & d & $20,11 b$ \\
\hline 2.50 & $2,98 \mathrm{ab}$ & $0,18 \mathrm{~b}$ & 1,48 & $66,94 \mathrm{ab}$ & 42,72 & $\mathrm{c}$ & $20,41 b$ \\
\hline 5.00 & $3,16 \mathrm{a}$ & $0,22 \mathrm{ab}$ & 1,69 & 73,88 a & 61,22 & b & $21,14 \mathrm{~b}$ \\
\hline 7.50 & $3,46 \mathrm{a}$ & $0,26 \mathrm{a}$ & 1,93 & $75,84 \mathrm{a}$ & 85,48 & $\mathrm{a}$ & $25,50 \mathrm{a}$ \\
\hline 10.00 & $3,74 \mathrm{a}$ & $0,27 \mathrm{a}$ & 1,94 & $76,38 \mathrm{a}$ & 89,34 & $\mathrm{a}$ & $26,89 \mathrm{a}$ \\
\hline
\end{tabular}

Keterangan: Angka-angka yang diikuti oleh huruf kecil yang sama adalah berbeda tidak nyata pada uji DNMRt taraf 0.05 .

Bobot kering jerami yang diperoleh akibat masukan kompos 2.50 sampai 10.00 ton $\mathrm{ha}^{-1}$ tidak berbeda nyata (Tabel 3), sedangkan untuk perolehan bobot kering biji dan 100 biji, input kompos 7.50 dan 10.00 ton ha $^{-1}$ relatif sama, yang berbeda nyata dengan tanpa kompos dan input kompos 2.50 dan 5.00 ton $\mathrm{ha}^{-1}$. Pertumbuhan tinggi tanaman dipengaruhi oleh ketersediaan unsur hara N, P, K, di dalam tanah. Jika ketersediaan unsur hara di dalam tanah cukup, maka pertambahan tinggi tanaman berlangsung baik. Subekti et al., (2007) mengemukakan bahwa memasuki massa generatif, tanaman menyerap $\mathrm{P}$ sekitar $50 \%$, yang diikuti hara $\mathrm{N}(60-70 \%)$ dan $\mathrm{K}(80$ $90 \%$ ). Walaupun pertumbuhan vegetatif bagus, belum menjamin kualitas produksi baik. Peningkatan input kompos $\mathrm{Tt}+\mathrm{JP}$, nyata pengaruhnya terhadap kadar $\mathrm{N}$ dan $\mathrm{P}$, namun tidak berpengaruh nyata terhadap $\mathrm{K}$ tanaman jagung.

Untuk kadar $\mathrm{N}$-tot daun, input kompos 2.50 sampai 10.00 ton ha $^{-1}$ relatif sama pengaruhnya, yang berbeda nyata dengan kontrol. Untuk kadar $\mathrm{P}_{\text {-tot }}$ daun tanaman jagung, pemberian 5.00 sampai 10.00ton ha ${ }^{-1}$ relatif sama, yang nyata dengan input 0.00 dan 2.50 ton ha $^{-1}$. Menurut Brady and Weil (2008),
$\mathrm{N}$ dalam tanah berasal dari $\mathrm{BO}$ tanah, pengikatan oleh mikroorganisme dan $\mathrm{N}$ udara, pupuk, serta air hujan.

Nilai $\mathrm{N}$-tot tanaman pada perlakuan kompos memiliki kisaran 2-3\%. Dibandingkan dengan batas kecukupan dan defisiensi unsur hara jagung (Sanchez, 1993), input kompos 0.00-2.50 tonha ${ }^{-1}$ belum mampu menyediakan $\mathrm{N}$ yang cukup bagi tanaman jagung karena batas antara kecukupan dan defisiensi unsur hara $\mathrm{N}$ tanaman jagung adalah 3\%.

Peningkatan dosis kompos juga berbeda nyata terhadap kandungan $\mathrm{P}_{- \text {tot }}$ tanaman jagung. Kandungan $\mathrm{P}_{\text {-tot }}$ tertinggi terdapat pada dosis kompos 10.00 tonha $^{-1}(0,27 \%)$ yang relatif sama dengan dosis 5.00 dan 7.50 tonha $^{-1}$. Nilai $\mathrm{P}_{\text {-tot }}$ terendah yaitu $0,16 \%$ terdapat pada dosis kompos 0.00 tonha $^{-1}$. Secara umum, pemberian kompos dapat meningkatkan kandungan $\mathrm{P}_{\text {-tot }}$ tanaman jagung. Jika nilai $\mathrm{P}_{\text {-tot }}$ dibandingkan dengan batas kecukupan dan defisiensi hara $\mathrm{P}$ tanaman jagung, hanya perlakuan kompos dosis 7.50 tonha $^{-1}$ dan 10.00 tonha $^{-1}$ yang memiliki kriteria $P$ yang cukup.

Pengaruh pemberian kompos berbeda tidak nyata terhadap kandungan $\mathrm{K}$-tot tanaman jagung, walaupun terjadi peningkatan nilai $\mathrm{K}$ seiring penambahan dosis kompos. Jika 
dibandingkan dengan kriteria kecukupan hara $\mathrm{K}$ tanaman jagung, hanya perlakuan kompos 7.50 dan dan 10.00 tonha $^{-1}$ yang memiliki kriteria $\mathrm{K}$ yang cukup. Batas kecukupan dan defisiensi unsur hara $\mathrm{K}$ untuk tanaman jagung yaitu 1,9\% (Sanchez,1993). Unsur K umumnya banyak terdapat dalam tanah, tetapi hanya sebagian yang digunakan tanaman yaitu yang larut dalam air atau yang dapat dipertukarkan.

Bobot jerami yang didapatkan peningkatan dosis kompos yang diberikan belum mempengaruhi secara nyata. Namun berbeda nyata dengan kontrol (Tabel 3). Untuk bobot biji kering terbanyak diperoleh pada input kompos 10.00 tonha $^{-1}$ (89.34g), yang relatif sama dengan input 7.50 tonha $^{-1}$. Sejalan dengan perolehan bobot kering biji, kualitas biji juga lebih baik pada input 10.00 tonha $^{-1}(26,89 \mathrm{~g})$, yang relatif sama 7.50 tonha $^{-1}$. Kualitas biji yang diperoleh juga telah sesuai dengan deskripsi tanaman jagung varitas NKK22. Hasil tanaman yang diperoleh sejalan dengan sifat kimia tanah yang belum terlalu mendukung untuk pertumbuhan tanaman jagung. Namun pada dosis 7,50tonha ${ }^{-1}$ lebih optimal dari input lainnya, sehingga bobot kering biji dan kualitas biji terbaik juga diperoleh pada input tersebut.

Hasil penelitian Rahni (2012), ternyata peningkatan bobot kering biji seiring dengan banyaknya translokasi fotosintat ke biji. Dan didukung juga oleh sistim perakaran yang semakin baik. Translokasi fotosintat yang lancar dan cukup ke organ reproduktif, akan merangsang pembentukan tongkol dan pengisian biji yang baik pula.

\section{KESIMPULAN}

Input kompos asal Titonia dan Jerami padi (1:1) dalam memperbaiki ciri kimia Ultisol, serta bobot kering jerami, bobot kering biji dan bobot 100 biji yang optimal diperoleh pada dosis 7.50 tonha $^{-1}$. Pada dosis tersebut, nilai $\mathrm{pH}$ tanah mencapai 6,18 satuan; $\mathrm{P}_{\text {-ters }}$ sebesar 17,64ppm, Kapasitas Tukar Kation (KTK) $18,38 \mathrm{cmol}(\mathrm{kg})^{-1}, \quad \mathrm{C}$-org, $1.27 \%, \quad \mathrm{~N}$-tot. $0,23 \% ， \quad \mathrm{~K}-\mathrm{dd} \quad 0,49 \mathrm{cmol}(\mathrm{kg})^{-11} ; \quad \mathrm{Ca}-\mathrm{dd}$ $2.63 \mathrm{cmol}(\mathrm{kg})^{-1} ; \mathrm{Mg}_{-d d} 0,57 \mathrm{cmol}(\mathrm{kg})^{-1}$ dan Nadd $0,39 \mathrm{cmol}(\mathrm{kg})^{-1}$; dengan produksi jagung optimum sebanyak 85,48 gpot $^{-1}$; bobot jerami

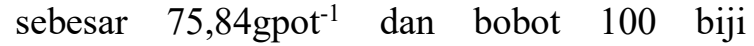
sebanyak $25,50 \mathrm{~g}$.

\section{UCAPAN TERIMAKASIH}

Terimakasih disampaikan pada mahasiswa dan analis yang telah membantu terlaksananya penelitian ini.

\section{DAFTAR PUSTAKA}

Brady, N.C. and Weil, R.R. 2002. The Nature and Properties of Soils. 13ed. Pearson Education, Inc., Upper Saddle River, New Jersey. 960p.

Departemen Pertanian. 2015. Pedoman Upaya Khusus (UPSUS) Peningkatan Produksi Padi, Jagung Dan Kedelai Melalui Program Perbaikan Jaringan Irigasi Dan Sarana Pendukungnya Tahun Anggaran 2015. Peraturan Mentri Nomor 03/Permentan/OT .140/2/2015. Mentri Pertanian Republik Indonesia. 33 hal

Gusnidar, Hakim, N. dan Prasetyo, T.B. 2010. Inkubasi Titonia pada Tanah Sawah terhadap Asam-asam Organik. Jurnal Solum Vol VII No. I. Hal 7-18.

Gusnidar., Yasin, S., Burbey dan Resi. 2011. Aplikasi Kompos Titonia Dan Jerami Terhadap Pengurangan Input Pupuk Buatan Dan Pengaruhnya Terhadap Produksi Padi. Padang. Jurnal Solum Vol. VIII No. 1 Januari 2011: 19-26.

Gusnidar, Fania, U., dan Gusmini. 2017. Titonia dan Jerami Padi yang Dikomposkan untuk Perbaikan Ciri Kimia Oxisol dan Produksi Cabay Kopay. Dalam Prosiding Seminar Nasional Lahan Sub Optimal, 19-20 Oktober 2017. Unsri. Palembang.

Hakim, N. 1982. Pengaruh pemberian pupuk hijau dan kapur pada Podzolik Merah Kuning terhadap keersediaan fosfor dan 
produksi tanaman jagung (Zea mays, L). Disertasi doktor. Fakultas pascasarjana IPB. Bogor. 272 hal.

Hanafiah, K.A. 2007. Dasar-dasar Ilmu Tanah. PT. Raja Grafindo. Jakarta. 359 hal.

Hardjowigeno, S. 2010. Ilmu Tanah. Akademika Pressindo. Jakarta. 268 hal.

Rahni, N. M. 2012. Efek Fitohormon PGPR terhadap Pertumbuhan Tanaman Jagung (Zea mays). Jurnal Agribisnis dan Pengembangan Wilayah Vol.3(2) 2 Juni 2012. 27-35p.

Sanchez, P.A. 1993. Jilid 2. Sifat dan Pengelolaan Tanah Tropika. Terjemahan oleh Hamzah, A. Penerbit ITB. Bandung. 302 hal.

Senesi, N., Xing, B., Huang, P. M. 2009. Biophysico-Chemical Processes Involving Natural non Living Organic Matter in Enviromental Systim. John Wiley, Publ. USA.

Soepardi, G. 1983. Sifat dan Ciri Tanah. Jurusan Tanah, Fakultas Pertanian, Institut Pertanian Bogor. Bogor. 591 hal.

Stevenson, F. J. 1982. Humus Chemistry, Genesis, Composition,
Reactions. $2^{\text {nd }} . \quad E d$. John Wiley and Sons, N. Y. 443 hal.

Subagyo, H.S., Nata., dan Siswanto, A.B. 2004. Tanah-tanah Pertanian di Indonesia dan Pengelolaannya. Pusat Penelitian Tanah dan Agroklimat, Badan Penelitian dan Pengembangan Pertanian, Departemen Pertanian, Bogor. Hal 2166.

Subekti, N.A. 2007. Morfologi Tanaman dan Fase Pertumbuhan Jagung. Dalam Jagung : Teknik Produksi dan Pengembangan. Balai Penelitian Tanaman Serealia. Maros. Hal 92.

Sudaryono. 2009. Tingkat Kesuburan Ultisol pada Lahan Pertambangan Batubara Sangatta Kalimantan Timur. Jurnal Teknologi Lingkungan. 10(3) : 337-346.

Tan, K. H. 2010. Dasar-Dasar Kimia Tanah . Terjemahan dari Principles of Soil Chemistry Fourth Edition. Oleh Didiek Hadjar Goenadi. Gadjah Mada University Press. Yogyakarta. 295 hal.

Yasin, S. Gusnidar, Suliansyah dan Juniarti. 2015. Pengaruh kapur dan bahan organik terhadap sifat kimia tanah serta produksi gandum (Triticum aestivum L.) di Alahan Panjang. Makalah disampaikan dalam seminar HITI Komda Aceh. Banda Aceh. 